\title{
The effect of lecturers' gender on the use of discourse markers
}

Rezaee, Mehrdad

PhD student, English Department, Science and Research Branch, Islamic Azad University, Tehran, Iran (Mehr351@yahoo.com)

Aghagolzadeh, Ferdows

Linguistic Department of Tarbiat Modares University (TMU), Tehran, Iran (aghagolz@modares.ac.ir)

Birjandi, Parviz

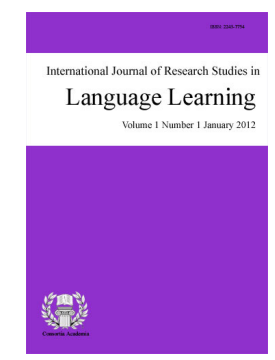

ISSN: 2243-7754 Online ISSN: 2243-7762

OPEN ACCESS

English Department, Science and Research Branch, Islamic Azad University, Tehran, Iran (birjandi@srbiau.ac.ir)

\section{Abstract}

This study is an attempt to see if there is any significant difference between Iranian and English male vs. female professors' use of four discourse markers (DMs) of 'well', 'OK', 'you know', and 'I mean' (as they are said to be the most frequently used DMs in English [Fuller, 2003]) in their academic lectures. For this purpose, some 20 lectures in Iranian context (10 male and 10 female lecturers' classes) were audio recorded and transcribed and then, they were compared with the transcription of 20 lectures with the same proportion in English context taken from MICASE. Based on the comparison, it was concluded that there are substantial quantitative and qualitative differences in the use of DMs and their pragmatic functions between Iranian and English male vs. female professors' lectures. This means that, the Iranian and English female professors used the four DMs much more frequently (significant quantitative difference) and also employed a wider range of the functions of the DMs (significant qualitative difference) compared to their male counterparts. Finally, some implications were presented.

Keywords: gender; discourse marker; function; frequency; academic lecture 


\section{The effect of lecturers' gender on the use of discourse markers}

\section{Introduction}

One of the features of human beings which distinguish him/her from animals is the ability to use language in the way we know, and one of the main purposes of using any language is to communicate. In fact, communication is viewed as a process of transferring thoughts from one person to another. This means that,

When we use language to say something to someone, we are intentionally communicating with that person (Yule, 2006, p. 8).

This communication can be about anything, ranging from feelings, ideas, thoughts, memories, and intentions to stories and anecdotes and even to scientific matters. Getting to the last one, when communication is about scientific matters, it is either between two people like two classmates, a teacher and a student, or it can be between a teacher and the whole class for the purpose of teaching. This is called a lecture which can occur at different levels, e.g., school or university, and when it is done at university level, it is called academic lecture (with its own characteristics) and it can be carried out in every academic field by university lecturers and professors to provide their students with the state of the art in their specific fields or it can be for the purpose of clarifying an ambiguous issue or to further students' knowledge in a specific area.

In recent years, there has been a growing interest in studying academic lectures from different viewpoints as some believe "Lectures in their many forms, are the most commonly used methods for transferring information" (Tehrani \& Dastjerdi, 2012, p. 423), because of internationalization of higher education both from the viewpoint of students and from that of teachers (Gomez \& Fortuño, 2005), and since lectures have "paradigmatic stature" (Waggoner, 1984, p. 9), or last but not least, because they are "the central ritual of the culture of learning" (Benson, 1994, p. 189). For the very same reasons, there have been several research projects on the use of the English language in academic discourse and its effect(s) on the way academic lectures are presented. Particularly, research studies on discourse markers and different aspects of lectures have made researchers interested in this area (e.g., Ädel, 2010; Chaudron \& Richards, 1986; Christodoulidou, 2011; Gomez \& Fortuño, 2005; Kaveifard \& Allami, 2011; Khedri, Ebrahimi, \& Heng, 2013; and Rashidi \& Alhosseini, 2012 to name but a few).

Despite researchers' interest in DMs, different researchers have employed different terms to call DMs and this shows the multifaceted functions performed by DMs in the organization of native speakers' spoken discourse (Shahbaz et al., 2013). Meanwhile, DMs have an indispensable role in oral interaction (Carter and McCarthy, 2006). Researchers define them differently since they view DMs from different viewpoints. That is why different scholars have assigned different names to them, such as 'discourse connectives' (Blakemore, 1987, 1992, 2002), 'semantic conjuncts' (Quirk et al., 1985), 'continuatives' (Halliday, 1994), 'pragmatic expressions' (Erman, 1987), 'pragmatic formatives' (Fraser, 1990), 'pragmatic markers' (Aijmer \& Simon-Vandenbergen, 2009; Andersen, 2001; Fraser, 1996; Schiffrin, 1987), 'pragmatic particles' (Tannen, 2007), 'filled pauses' (Swerts, 1998), 'discourse fillers' (Navas Brenes, 2005; Watanabe, 2002), 'discourse operators' (Redeker, 1990), 'discourse particles' (Baker, 2010; Fischer, 2000; Jones, 1992), and last but not least, 'discourse markers' (Fox Tree \& Schrock, 2002; Mesthrie, 2001).

Consequently, different definitions for discourse markers have been put forth. From one point of view, we can go with Schiffrin's (1987) definition that discourse markers are "sequentially dependent elements which bracket units of talk" (p. 31). With the phrase, 'sequential dependence', she means that the markers work on the discourse level. From another point of view, we can say that discourse markers are words or phrases that are relatively syntax-independent and do not change the meaning of the sentence. Similarly, Nosek (1987) believes that "Discourse markers are constitutive elements that are semantically void" (p. 159). In his idea, "The elements that we now term 'discourse markers' are situated outside the Theme" (Nosek, 1987, p. 160). This definition 
The effect of lecturers' gender on the use of discourse markers

partly agrees with what Richards and Schmidt (2010) state for discourse markers regarding the 'semantically void' nature of discourse markers as

Expressions that typically connect two segments of discourse but do not contribute to the meaning of either (Richards \& Schmidt, 2010, p. 162).

Too, in line with Richards and Schmidt is Andersen (2001) who believes that "they are necessarily external to propositions and do not contribute to truth conditions" (p. 38).

Similar to the definition of DMs, functions of DMs have been considered from different perspectives. Some have claimed that understanding the role of discourse markers and the relationship between different parts of the text is essential for the comprehension of lectures (Chaudron \& Richards, 1986; Rido, 2010; Shahbaz et al., 2013; Smit, 2009). Another group of researchers are concerned with features of discourse organization (Chaudron, 1983; Chaudron \& Richards, 1986; Christodoulidou, 2011; Othman, 2010; Eslami Rasekh et al., 2012, to name but a few). Last but not least, some other researchers believe that

DMs (such as 'okay', 'all right', articulated pauses, strategic silence) can be used in lectures to frame transactions and exchanges (Rose, 1998, p. 13).

According to him, DMs can take the role of shaping exchanges and transactions in lectures. Too, it has been discovered that DMs perform on different functional levels depending on various pedagogical aims, although one should know that it is very much difficult to categorize discourse markers based on their function (Christodoulidou, 2011).

To narrow it down to classroom context, a large number of research projects have been carried out on the functions of DMs in the presentation of lecture as an academic genre (Bellés Fortuño, 2006; Fraser, 1999; Holzschuh, 2013; Jucker, 1993; Lee, 2011; Lee \& Hsieh, 2004; Li \& Xiao, 2012; Liao, 2008; Othman, 2010; Shahbaz et al., 2013; Trihartanti \& Damayanti, 2013; and Zarei, 2013 to name but a few). As an example, Fraser (1999) studied discourse markers from a grammatical-pragmatic point of view and concluded by presenting what appear to be the major classes of DMs according to their function. Meanwhile, Bellés Fortuño (2006) carried out a contrastive study between English and Spanish languages in using different types of DMs in academic lectures and came to the conclusion that there is a difference between the type and amount of DM use between American and Spanish languages regarding university lectures and this leads to different rhetorical strategies used by English and Spanish university lecturers which may be either because of the difference between the two languages or due to the difference between the culture of the two languages.

Apart from the role of DMs, the there are other issues such as gender which in one way or another might affect the quality of lecture presentation. Few researchers (Koczogh \& Furko, 2011) state that gender has no role in the type of DMs used in lectures by saying there are no substantial quantitative differences in the DM use of men and women (p. 10), most others working in this area believe that gender influences the quality of lecture presentation (Alami \& Sabbah, 2012; Chun, 2008; Escalera, 2006; Kim \& Kang, 2011; Kyratzis \& Ervin Tripp, 1999; Liao, 2008; Matei, 2011; Mei, 2006; Winkler, 2008, to name but a few), but each of them sees this influence from a specific perspective. As an example, Escalera (2006) believes that,

There is gender difference in the use of DMs, but this difference would not be significant when discourse marker use is examined within a given activity context such as role-play (Escalera, 2006, p. 2490).

However, Mei (2006) has a different opinion by stating, "In oral English, men and women speak English in different ways based on different employment of discourse markers. Women generally discuss their personal feelings more than men. Men appear to prefer non-personal topics such as sport and news" (pp. 66-67). Nevertheless, Chun (2008) looks at the issue from the perspective of discourse marker type and states, "There are some significant differences found in the use of inferential and emphatic markers" (p. 33). According to him, 
"Female students used more emphatic markers, while male students tend to use more inferential markers" (Chun, 2008, p. 34). Too, Croucher (2004) believes that "The effect of gender on DM use varies with the type of discourse markers" (p. 44). However, he continues by saying that,

There is no significant difference between speakers' gender regarding their usage of two of the markers (um, uh), but there is a significant gender difference in the usage of the other two markers (like, you know) (Croucher, 2004, p. 44).

Winkler (2008), too, agrees with both Chun (2008) and Croucher (2004) but looks at the issue from a broader perspective and believes that there is a great difference "between the amount and also type of DMs used by females and males" (p. 69). Nonetheless, Liao (2008) believes that there is more gender difference between non-native male and female speakers when she says, "Studies show gender differences in the use of DMs by NNSs" (p. 14). Still, Matei (2011) has a different idea because she looks at the issue from pragmatic function of DMs when she says, "Variables like gender influence the main pragmatic functions that literature has ascribed to markers" (p. 219). In her idea, "It is the core pragmatic meaning of DMs that establish a general pattern of use" (Matei, 2011, p. 219).

In line with Matei (2011), Alami and Sabbah (2012) believe that
The difference between Persian men-women discourse in terms of DMs usage is of functional type rather than quantitative where the gender of the speaker does seem to be an influencing factor in DMs usage (Alami \& Sabbah, 2012, p. 157).

In other words, function of DMs affects what type of DM different genders choose in their discourse.

And finally is Kim and Kang (2011) who look at the emotional aspect of gender role in speakers' choice of DMs and notes, "Women respond more emotionally than men, and use more discourse markers than them" (p. 31). Meanwhile, they add that the type of speech determines men and women's choice of DMs by saying, "There are differences between men and women's private speech, especially discourse markers" (Kim \& Kang, 2011, P. 32).

However, there is no consensus among researchers regarding the role of gender in the quality of lecture presentation. For instance, Vanda and Péter (2011) claim that, "There are no substantial quantitative differences in the DM use of men and women" (p. 10). In their idea, gender has no influence on the type of DMs used by speakers. In line with Vanda and Péter (2011) is Schleef (2008) who has the same idea and believes that no role can be assigned to gender in the choice of DMs. In his words, "Gender plays no role at all in speakers' use of DMs" (p. 78). However, Beeching (2002) has a different idea about the role that gender plays in the use of DMs. In her opinion, gender has a 'preferential' role rather than an 'exclusive' one in what type of DM to use. This means that there are "gender-preferential rather than gender-exclusive difference" (p. 6) regarding the use of DMs.

Considering the disagreement ,the present study was conducted in order to explore if Iranian and English lecturers' gender can have any effect on the use of DMs such as 'You know', 'I mean', 'Well', and 'OK' \{ which are assumed to be the most frequently used DMs in English (Fuller, 2003) \} and their pragmatic functions. It is worth mentioning that few research studies have been conducted in the Iranian context on the difference between Iranian male and female and also English male and female university lecturer's use of discourse markers and their functions. Furthermore, the few ones which worked in this area, considered DMs in general; however, the present study has concentrated on just four of the DMs ('You know', 'I mean', 'Well', and 'OK'). So, the following research question was posed.

$>\quad$ What significant difference exists between male and female Iranian and English university professors' lectures in terms of using DMs and their pragmatic functions? 


\section{Method}

\subsection{Corpus Selection and Description}

In order to reach the objectives of this study, the researchers gathered a corpus with a total amount of forty spoken lecture transcripts. Due to the contrastive nature of this study, half of the corpus (twenty lectures) consisted of Iranian professors' lectures presented in English and the other half was English professors' lectures again presented in English. Of the 40 lectures in this study, some were more monologue where one speaker (the instructor) monopolized the floor, sometimes followed by question and answer periods and some were more interactive where the instructor and students interacted in the class. This means that all the lectures were in academic genre (followed by some questions and answers at the end). The lectures were all in the area of English Language Teaching (ELT).

The Iranian part of the corpus consisted of twenty lectures (presented in English to both MA and PhD level students) at different Azad and State universities. These lectures were recorded and transcribed for the purpose of this dissertation. Since this is a comparative study, a corpus of English lectures (presented in English at English Universities) were also collected. A data source in this regard is the English lectures previously transcribed by MICASE (Michigan Corpus of Academic Spoken English) (R.C. Simpson, S.L. Briggs, J. Ovens, \& J. M. Swales, 2002) and are available on the Internet thanks to the English Language Institute at the University of Michigan. It is worth mentioning that, in the MICASE corpus, speech events are categorized according to classroom events and non-class events. Since this study focuses on academic classroom lectures, and because all the lectures were presented by university instructors, only lectures which were informally presented (delivered ad hoc by an instructor, without reading from a written text) by both Iranian and English professors were recorded. As to the Iranian part of the lecture, firstly, some lecturers (only PhD holders) were selected and contacted in order to get their approval to record their classroom lectures. Meanwhile, throughout recording the lectures by Iranian professors, one of the researchers was personally present in the classes in order to do classroom observations. The researchers asked the lecturers not to inform students that the classes were being recorded so that they would have a natural behavior. Regarding the participants, the students and teachers involved in the lectures presented in the foreign universities were either English native speakers or had been living in the English speaking country for some years (ENSs); however, the students and teachers involved in Iranian universities were Iranian Native Speakers (INSs).

Based on the number of students in a class, since the number of $\mathrm{PhD} / \mathrm{MA}$ students in Iranian universities does not exceed 40, the researchers only examined Small Lectures (SL) and focused on MA/PhD classes in the field of English Language Teaching (ELT) at different branches of both Azad University and State Universities. As to the lectures presented in English universities, the researchers intended to choose the files of the lectures presented to Small Lecture (SL) classes at English universities (available at MICASE), so that the number of students at both Iranian and English universities were almost equal. It should be mentioned that only the corpus of academic lectures in the field of education (Teaching English as a Foreign Language, TEFL) will be used for this study.

MICASE \{Michigan Corpus of Spoken Academic English\} which is available through an on-line search engine is a collection of almost 200 hours of recordings from the University of Michigan (U-M) in Ann Arbor, designed and created between the years 1997-2002 by researchers and students at the U-M English Language Institute (ELI) to digitally audio-record and transcribe about 1.8 million words of academic speech at an American university, which covers speech events ranging from advising sessions for freshman students up to defense sessions of doctoral together with traditional university lectures and discussions taken place in the classroom. It includes data from a wide range of speech events \{including Large Lectures (40+ students, Small Lectures (under 40 students), classroom discussions, lab sections, seminars, and advising sessions \} and locations across the university. It has categorized important information about the lectures according to the traits found in 
them. Attributes such as title, primary discourse mode, speech event, number of words, as well as recording duration have been presented in MICASE (Simpson, Briggs, Ovens, \& Swales, 2002).

After recording the lectures, they were transferred to a computer and saved as audio files, and later, the transcribing process began. For each lecture, a transcribed draft was prepared. The draft were proofread and checked to include all the verbal events which took place in the class. The final transcript was ready for description and analysis. Lecturers' gender was also taken into account. For the Iranian part, the researchers recorded the lectures presented by both male and female lecturers, having 10 male and 10 female lecturers. Too, as for the English part, the same number and proportion of gender-based presentations were considered.

\subsection{Data analysis}

In order to analyze the data and find the frequency of the use of DMs in each of the two settings (Iranian and English), together with other features stated in the research questions, WordSmith version 4.0, a concordance software program was used. The variables used for the analysis of DMs were the frequency rate of each pre-established DM in the two sub-corpora together with their pragmatic functions by each gender. Nevertheless, it should be mentioned that, the present study works on the functions of four DMs of 'You know', 'I mean', 'Well', and 'OK' as they have been said to be the most frequently used DMs in English (Fuller, 2003). To analyze the results of the present study, the researchers used a collection of functions proposed by different scholars (Cohen, 2007; Jucker, 1993; Lee, 2011; and Li \& Xiao, 2012 for 'Well'; Christodoulidou, 2011; Liao, 2008; Othman, 2010; for 'OK'; and Mei, 2012 for both 'You know' and 'I mean') to come up with a comprehensive scope of the possible functions for each DM.

This study is contrastive and descriptive in nature, and so, it is a qualitative research. After collecting and transcribing the data and analyzing them, the researchers tried to make a comparison and a contrast between the lectures presented by Iranian lecturers and those of the English ones to see if the lecturers' gender has any effect on the discourse markers used by them together with the pragmatic functions of those discourse markers.

\section{Result and discussion}

To see if there is any significant difference between the two genders (of Iranian versus English male and female lecturers) regarding the use of discourse markers and their pragmatic functions, the researchers compared the frequency rate of the DMs with the functions used by each gender in this qualitative research. It should be noted that mean and t-test cannot be used for such a purpose in the present study since

Parametric statistics is based on the assumption of normal distribution and in case of small samples, normal distribution cannot be attained (Asthana \& Bhushan, 2010, p. 6).

Accordingly, only the frequencies were reported. In qualitative research frequencies replace, "the notion of significance" and it is the "interpretation of the researcher [which] gives depth and meaning to the frequency obtained" (Asthana \& Bhushan, 2010, p. 5). Put another way, "Frequency equals significance" (Hitchcock \& Hughes, 2003, p. 226).

To put it in a nutshell, after tabulating the obtained frequencies, the descriptive analysis was presented by the researchers as follows. It is worth mentioning that, the total number of words used in Iranian male vs. female professors' lectures were 134080 and 131096, respectively, while the total number of words used in English male vs. female professors' lectures were 135729 and 135970, respectively. In the meantime, Table 1 displays a summary of the number of each of the DMs used in the lectures of Iranian male vs. female and English male vs. female professors. 
The effect of lecturers' gender on the use of discourse markers

Table 1

Number of Each DM Used by Iranian Male/Female vs. English Male/Female Professors

\begin{tabular}{ccccc}
\hline $\begin{array}{c}\text { Type of } \\
\text { DM }\end{array}$ & $\begin{array}{c}\text { Iranian Male } \\
\text { Professors }\end{array}$ & $\begin{array}{c}\text { Iranian Female } \\
\text { Professors }\end{array}$ & $\begin{array}{c}\text { English Male } \\
\text { Professors }\end{array}$ & $\begin{array}{c}\text { English Female } \\
\text { Professors }\end{array}$ \\
\hline Well & 319 & 360 & 540 & 1100 \\
OK & 729 & 920 & 780 & 970 \\
You know & 749 & 395 & 732 & 1450 \\
I mean & 270 & 156 & 256 & 820 \\
\hline
\end{tabular}

Table 2

Frequency $(F)$ of Different Functions of 'well' in Iranian Male/Female Professors' Lectures

\begin{tabular}{ccccccc}
\hline & \multicolumn{3}{c}{ Iranian Male Professors } & \multicolumn{3}{c}{ Iranian Female Professors } \\
\cline { 2 - 6 } Discourse Marker 'Well' & $\mathrm{F}$ & $\mathrm{RF}$ & $\mathrm{P}$ & $\mathrm{F}$ & $\mathrm{RF}$ & $\mathrm{P}$ \\
\hline Topic change & 0 & 0 & $0 \%$ & 24 & .066 & $6.6 \%$ \\
Dispreferral & 18 & .056 & $5.6 \%$ & 40 & .111 & $11.1 \%$ \\
Turn-taking & 54 & .169 & $16.9 \%$ & 56 & .155 & $15.5 \%$ \\
Repair Marker & 54 & .169 & $16.9 \%$ & 32 & .088 & $8.8 \%$ \\
Initiation Marker & 103 & .322 & $32.2 \%$ & 80 & .222 & $22.2 \%$ \\
Delay Marker & 54 & .169 & $16.9 \%$ & 104 & .288 & $28.8 \%$ \\
Face-Threat Mitigator & 36 & .112 & $11.2 \%$ & 24 & .066 & $6.6 \%$ \\
\hline
\end{tabular}

As illustrated in Table 2, there is no specific difference between Iranian male and female professors in the overall use of 'Well' as a discourse marker. That is while there were 319 cases of 'well' used by male professors (in 10 lectures, each presented by 1 professor), 360 cases of 'well' were used by female professors (in 10 lectures, each presented by 1 professor) which does not show a significant difference between the two groups. So, quantitatively, there was no significant difference between the two groups regarding the use of 'well'. However, as to the functions of 'well' there seems to be difference in some parts. For the very first function (Topic-change), none of the male professors seem to have used 'well' in their lectures. This shows that male professors did not have tendency to use 'well' either to change the stream of talk or to quote someone else in their presentations. However, there were 24 cases of 'well' in the lectures presented by female professors to be used either to change the stream of talk while they were presenting lecture or to quote someone else in their presentations. Too, regarding the function of 'dispreferral', it can be seen that women used double cases of 'well' for this function than men. That is, while there were 40 cases of 'well' by female professors, only 18 cases were used by male professors. This means that, female professors showed more tendency than male professors to give indirect replies to the questions asked and were more willing to respond in a way that was not what they really wanted to say.

As to the function of 'Turn-taking', there seems to be no specific difference between the two genders, but regarding the functions of 'repair-marker' and 'initiation-marker', more difference is apparent between male and female genders as it shows 54 cases for Male and 32 for female professors and 103 cases for male and 80 cases for female professors, respectively, though they are not as significant as the first and second functions. Next comes the function of 'delay marker' in which similar to the function of 'dispreferral', females used 'well' almost twice more than male professors. This means that female professors needed more time for thinking than male professors when asked questions and for this purpose, they used more cases of 'well' in their presentations than male professors. Last but not least in this Table is the function of 'face-threat mitigator' in which male professors used more instances of 'well' to mitigate face-threat than female professors. This can show that male professors used were more instances of 'well' than female professors in their disagreement, disapproval, or in rejecting requests made by their students and as a result, they tried more to decrease any possible face-threat by using 'well' in their presentations. 
Rezaee, M., Aghagolzadeh, F., \& Birjandi, P.

Tables 3

Frequency (F) of Different Functions of 'well' in English Male/Female Professors' Lectures

\begin{tabular}{ccccccc}
\hline & \multicolumn{3}{c}{ English Male Professors } & \multicolumn{2}{c}{ English Female Professors } \\
\cline { 2 - 6 } Discourse Marker 'Well' & $\mathrm{F}$ & $\mathrm{RF}$ & $\mathrm{P}$ & $\mathrm{F}$ & $\mathrm{RF}$ & $\mathrm{P}$ \\
\hline Topic change & 60 & .111 & $11.1 \%$ & 20 & .018 & $1.8 \%$ \\
Dispreferral & 0 & 0 & $0 \%$ & 40 & .036 & $3.6 \%$ \\
Turn-taking & 130 & .24 & $24 \%$ & 260 & .236 & $23.6 \%$ \\
Repair Marker & 50 & .092 & $9.2 \%$ & 140 & .127 & $12.7 \%$ \\
Initiation Marker & 160 & .296 & $29.6 \%$ & 290 & .263 & $26.3 \%$ \\
Delay Marker & 120 & .222 & $22.2 \%$ & 240 & .218 & $21.8 \%$ \\
Face-Threat Mitigator & 20 & .037 & $3.7 \%$ & 110 & .1 & $10 \%$ \\
\hline
\end{tabular}

Table 3 shows a significant difference between the two groups regarding the instances of 'well' used by them ( 540 by male vs. 1100 by female). In other words, the instances of 'well' used by female professors was double that of male ones). So, quantitatively, there was a significant difference between the two groups. Meanwhile, there is a significant difference between male and female professors regarding the instances of 'well' used in either of the functions. Therefore, besides significant quantitative difference, Table 3 shows a great difference in the instances of 'well' for each function by the two groups of male and female professors.

As to the first function of Table 3 (Topic change), male professors used 'well' three times more for the function of 'topic change' than female professors (60 vs. 20). This means that, male professors had three times more tendency than female ones to use 'well' either to change the stream of talk or to quote someone else in their presentations. However, regarding the function of 'dispreferral', male professors did not use any instance of 'well' for this function, while there were 40 instances of 'well' used by female professors in their lectures. In other words, female professors had more willingness than male professors to give indirect responses to the questions asked and had more tendency to reply in a way that was not what they really intended to say. Nevertheless, in the function of 'turn-taking', male professors used 130 instances of 'well', but this was half of what female professors used (260 instances) in their lectures. This means that, female professors had more willingness than male professors to take the pace of speech while another person was speaking and to show that they would like to be the next speaker by using 'well' at the beginning of their speech. Similar to 'turn-taking' but with a more significant difference, in the function of 'repair-marker', female professors used many more instances of 'well' (140 vs. 50) and this can mean that they had (almost three time) more tendency to correct/rephrase what they had said by using 'well' while still speaking. As to the functions of 'initiation marker' and 'delay marker', and similar to 'turn-taking' function, female professors used almost twice as many instance of 'well' as male ones to begin their speech after being said something or to pause to think about what to say in reply to what has been mentioned to them or the questions asked from them. Last but not least, regarding the function of 'face-threat mitigator, there is a very much significant difference between the two groups of professors as female professors used more than 5 times as many instances of 'well' to mitigate the possible threat of disagreement, disapproval or rejection of requests made by their audience (students).

Table 4

Frequency $(F)$ of Different Functions of 'OK' in Iranian Male/Female Professors' Lectures

\begin{tabular}{ccccccc}
\hline & \multicolumn{3}{c}{ Iranian Male Professors } & \multicolumn{3}{c}{ Iranian Female Professors } \\
\cline { 2 - 6 } Discourse Marker 'OK' & $\mathrm{F}$ & $\mathrm{RF}$ & $\mathrm{P}$ & $\mathrm{F}$ & $\mathrm{RF}$ & $\mathrm{P}$ \\
\hline Initiate Movement toward Closure & 53 & .073 & $7.3 \%$ & 48 & .052 & $5.2 \%$ \\
Check Progression & 214 & .29 & $29 \%$ & 360 & .39 & $39 \%$ \\
Mark Transition to the Next Utterance & 71 & .097 & $9.7 \%$ & 72 & .078 & $7.8 \%$ \\
Check Students' Comprehension & 0 & 0 & $0 \%$ & 0 & 0 & $0 \%$ \\
Ask for Confirmation & 0 & 0 & $0 \%$ & 0 & 0 & $0 \%$ \\
Response Elicitor & 0 & 0 & $0 \%$ & 0 & 0 & $0 \%$ \\
Sentence-Opener & 178 & .24 & $24 \%$ & 184 & .2 & $20 \%$ \\
Consent & 80 & .11 & $11 \%$ & 144 & .156 & $15.6 \%$ \\
Unidentified & 133 & .182 & $18.2 \%$ & 112 & .12 & $12 \%$ \\
\hline
\end{tabular}


Table 4 shows the difference between Iranian male and female professors regarding the instances of ' $O K$ ' in their lectures (729 for male vs. 920 for female professors) which is not highly significant, though the significance is not ignorable, either. So, quantitatively, the difference is not so significant. One major difference between 'well' and 'OK' is that the latter has been categorized into 'Rising tone' and 'Falling tone' regarding the way it is produced in spoken language. In fact, Liao (2008) and Othman (2010) believe that except functions such as 'response elicitor' and 'consent' which are produced with a rising tone, the other functions are produced with a falling tone. Having these in mind and taking a look at Table 4, one can see that, as to the different functions for which 'OK' has been used by both groups, there is no difference at all in three of the functions (Check Students' Comprehension, ask for Confirmation, and response-elicitor) as neither group used 'OK' to carry out those functions. In other words, neither group used 'OK' to get verbal response from the students and this might be because they didn't deem it necessary to get any verbal response or confirmation from their students for what they said. In the meantime, both groups used ' $O K$ ' almost the same number of times (71 for male vs. 72 for female) to carry out the function of 'mark transition to the next utterance' to make a relation between what has been said before and what is going to be said next.

The other functions in which there was not a significant difference between male and female professors regarding the instances of ' $O K$ ' was 'sentence-opener' (178 for male vs. 184 for female professors) and 'initiate movement toward closure' (53 for male vs. 48 for female professors). In fact, both female and male professors used almost the same instances of ' $\mathrm{OK}$ ' in their lectures for the two functions. Besides these, however, there was a significant difference between the two groups in two of the functions, namely, 'check progression' and 'consent'. In the former one, male professors used 214 instances of 'OK' in their lectures while female ones used almost 1.5 times more instances of 'OK' in their presentations. Accordingly, one can infer that female professors used almost 1.5 times more instances of ' $O K$ ' to check whether or not what they said to the audience was comprehensible for them without really intending to get verbal response from the students. Too, in the latter one, female professors used almost double the number of cases of ' $O K$ ' in their lectures and this shows that female professors used more instances of 'OK' than male ones for the purpose of agreement with what was said to them or approval of what they heard. Besides what was mentioned above regarding different functions of 'OK', both male and female professors used some instances of 'OK' in their lectures (133 for male and 112 for female professors) which could not be deemed under any of the presented categories and were named 'unspecified'.

\section{Table 5}

Frequency (F) of Different Functions of 'OK' in English Male/Female Professors' Lectures

\begin{tabular}{ccccccc}
\hline & \multicolumn{3}{c}{ English Male Professors } & \multicolumn{3}{c}{ English Female Professors } \\
\cline { 2 - 7 } Discourse Marker 'OK' & $\mathrm{F}$ & $\mathrm{RF}$ & $\mathrm{P}$ & $\mathrm{F}$ & $\mathrm{RF}$ & $\mathrm{P}$ \\
\hline Initiate Movement toward Closure & 148 & .19 & $19 \%$ & 90 & .09 & $9 \%$ \\
Check Progression & 132 & .17 & $17 \%$ & 273 & .28 & $28 \%$ \\
Mark Transition to the Next Utterance & 158 & .20 & $20 \%$ & 89 & .33 & $33 \%$ \\
Check Students' Comprehension & 0 & 0 & $0 \%$ & 0 & 0 & $\%$ \\
Ask for Confirmation & 30 & .038 & $3.8 \%$ & 0 & 0 & $\%$ \\
Response Elicitor & 0 & 0 & $0 \%$ & 0 & 0 & $\%$ \\
Sentence-Opener & 139 & .178 & $17.8 \%$ & 157 & .16 & $16 \%$ \\
Consent & 114 & .146 & $14.6 \%$ & 322 & .33 & $33 \%$ \\
Unidentified & 59 & .075 & $7.5 \%$ & 39 & .04 & $4 \%$ \\
\hline
\end{tabular}

In table 5, it can be seen that quantitatively, there is a difference between the two groups of male and female professors (780 for male vs. 970 for female professors) regarding the number of times 'OK' was used in their lectures; however, this difference was not so significant, though it was not negligible either. Nevertheless, regarding functions, there seemed to be three classifications. As to the first classification, in some functions (Check Students' Comprehension and response elicitor), there was no difference between the two groups at all as none of the two groups used 'OK' in the mentioned function.

Regarding the second classification, there seemed to be a difference regarding the number of times 'OK' 
Rezaee, M., Aghagolzadeh, F., \& Birjandi, P.

was used for the function of 'sentence-opener' between the two groups (139 for male vs. 157 for female) but this difference was not very much significant. As to the third classification, there seems to be a significant difference between the two groups. For example in the functions of 'ask for confirmation' male professors used them for 30 times but female ones did not use them at all. Put another way, male professors used 'OK' for 30 times to get confirmation about what they said to their students while female professors did not use 'OK' for this purpose at all. Too, in the function of 'Initiate Movement toward Closure', male professors used 148 cases of 'OK' but female professors used 90 instances of them to carry out this function. In other words, male professors used 1.5 times more cases of 'OK' than female ones to make closure between previous and next issues of their utterances.

Meanwhile, as to the function of 'check progression', it can be mentioned by looking at Table 5 that, female professors used 'OK' more than twice the number of times male professors did probably to check whether or not what they said to the students was comprehensible for them without really intending to get verbal response from them. Similar to 'initiate movement toward closure', is the function of 'mark transition to the next utterance' in which male professors used more than 1.5 times more cases of 'OK' in their lectures to make relation between previous and coming utterances. However, the function of 'consent' is similar to the function of 'check progression' in which female professors used 'OK' for some 322 times while male professors used it for 114 times to show their agreement with what was said to them or demonstrate their approval. Besides what was mentioned above regarding different functions of 'OK', both male and female professors used some instances of ' $\mathrm{OK}$ ' in their lectures (59 for male and 39 for female professors) which could not be deemed under any of the presented categories and were named 'unspecified'.

Table 6

Frequency of Different Functions of 'you know' in Iranian Male/Female Professors' Lectures

\begin{tabular}{|c|c|c|c|c|c|c|}
\hline \multirow[b]{2}{*}{ Discourse Marker 'You know' } & \multicolumn{3}{|c|}{ Iranian Male Professors } & \multicolumn{3}{|c|}{ Iranian Female Professors } \\
\hline & $\mathrm{F}$ & $\mathrm{RF}$ & $\mathrm{P}$ & $\mathrm{F}$ & RF & $\mathrm{P}$ \\
\hline Hearer-oriented & 485 & .647 & $64.7 \%$ & 168 & .423 & $42.3 \%$ \\
\hline Assumption-correction & 0 & 0 & $0 \%$ & 0 & 0 & $0 \%$ \\
\hline Introducing background information & 25 & .033 & $3.33 \%$ & 0 & 0 & $0 \%$ \\
\hline Cause & 24 & .032 & $3.2 \%$ & 0 & 0 & $0 \%$ \\
\hline Reason & 11 & .0146 & $1.46 \%$ & 0 & 0 & $0 \%$ \\
\hline Result & 21 & .028 & $2.8 \%$ & 34 & .086 & $8.6 \%$ \\
\hline Explicitness & 97 & .1295 & $12.95 \%$ & 26 & .065 & $6.6 \%$ \\
\hline Reformulation & 96 & .1281 & $12.81 \%$ & 21 & .053 & $5.3 \%$ \\
\hline Exemplification & 148 & .197 & $19.7 \%$ & 53 & .134 & $13.4 \%$ \\
\hline Seeking confirmation & 0 & 0 & $0 \%$ & 0 & 0 & $0 \%$ \\
\hline Summarization & 5 & .0066 & $.66 \%$ & 29 & .073 & $7.3 \%$ \\
\hline Quotative & 33 & .044 & $4.4 \%$ & 5 & .012 & $1.2 \%$ \\
\hline Interactant-relationship-oriented & 56 & .074 & $7.4 \%$ & 34 & .0848 & $8.4 \%$ \\
\hline Justification & 20 & .026 & $2.6 \%$ & 0 & 0 & $0 \%$ \\
\hline Conclusion & 0 & 0 & $0 \%$ & 0 & 0 & $0 \%$ \\
\hline Softener of FTA & 31 & .041 & $4.1 \%$ & 13 & .033 & $3.3 \%$ \\
\hline Interactional repair & 0 & 0 & $0 \%$ & 0 & 0 & $0 \%$ \\
\hline Indicating marked expressions & 0 & 0 & $0 \%$ & 0 & 0 & $0 \%$ \\
\hline Indicating the most likely event & 0 & 0 & $0 \%$ & 7 & .0177 & $1.77 \%$ \\
\hline $\begin{array}{l}\text { Indicating the unspoken message to be } \\
\text { completed by the hearer }\end{array}$ & 5 & .0066 & $.66 \%$ & 6 & .0151 & $1.51 \%$ \\
\hline $\begin{array}{l}\text { Indicating the coming message is } \\
\text { meant to be evaluated }\end{array}$ & 0 & 0 & $0 \%$ & 8 & .020 & $2 \%$ \\
\hline Speaker-oriented & 208 & .277 & $27.7 \%$ & 193 & .4861 & $48.61 \%$ \\
\hline Hesitation marker & 49 & .065 & $6.5 \%$ & 59 & .149 & $14.9 \%$ \\
\hline Restart & 85 & .113 & $11.3 \%$ & 56 & .141 & $14.1 \%$ \\
\hline Approximator & 26 & .034 & $3.4 \%$ & 6 & .0151 & $1.51 \%$ \\
\hline Introducing a new topic & 0 & 0 & $0 \%$ & 18 & .045 & $4.5 \%$ \\
\hline Indicating speaker attitude & 15 & .02 & $2 \%$ & 14 & .035 & $3.5 \%$ \\
\hline Mere filler & 33 & .044 & $4.4 \%$ & 40 & .101 & $10.1 \%$ \\
\hline
\end{tabular}


As to Table 6, it is clear that there are two major differences between this one (functions of 'you know') and Tables 2 and 4 (functions of 'well' and 'OK'). The very first difference is that, in Table 6, the functions of 'you know' have been categorized under three sub-parts (hearer-oriented, Interactant-relationship-oriented, and speaker-oriented) whereas this is not the case with the functions of 'well' and 'OK'. The other difference is that there was a difference between Iranian male and female professors regarding the number of times they had used 'well', and 'OK' in their lectures but this difference was not so significant; however, the difference between Iranian male and female professors regarding the number of times they used 'you know' in their lectures was completely significant as male professors used almost twice as many as female professors (749 cases for male professors vs. 395 for female professors). Besides, male professors on the whole used more cases of 'you know' in any of the three sub-parts separately (485 cases for male vs. 168 for female in hearer-oriented; 56 cases for male vs. 34 for female in interactant-relationship-oriented; and 208 cases for male vs. 193 for female in speaker-oriented).

Among the three sub-parts, 'hearer-oriented' had the most significant difference between male and female professors regarding the number of times 'you know' was used. It should be mentioned, though, that in some of the functions under each of these sub-parts, female professors used more cases of 'you know'. By all these, it can be suggested that overall, Iranian male professors used 'you know' by far more than female professors but only in the first sub-part (where the orientation was on the listener(s)), male professors used a wider range of functions than female; nevertheless, in the second and third sub-parts (where the orientation was on the speaker, or on the interaction between the speaker and the listener(s)) female professors used a wider range of functions than male professors. To get into more detail, one can see that in the 'hearer-oriented' part, female professors did not use five of the functions (assumption-correction, introducing background information, cause, reason, and seeking confirmation) at all, while male professors did not use only 2 of them (assumption-correction and seeking confirmation). Too, except the function of 'result', male professors used more cases of 'you know' than female professors.

It is worth mentioning that only in three of the functions, there was a significant difference between the number of times 'you know' was used by male and female professors and in the rest of them, the difference was insignificant, though not ignorable. As to the sub-part of 'interactant-relationship-oriented', though male professors used more instances of 'you know' than female professors from an overall viewpoint, they didn't use five of the functions under this sub-part at all and just used three of them, while female professors used four of the eight functions under this sub-part; however, in all of those three functions, male professors used higher instances of 'you know' than female professors. The difference between the functions under this sub-part is not as significant as the previous sub-part. As to the last sub-part (speaker-oriented), it can be seen that except for the functions of 'hesitation marker' and 'introducing a new topic', male professors used more instances of 'you know' for the rest of the functions. Finally, some cases of 'you know' were not suitable for any of the above-mentioned functions and in fact, they were merely used as fillers with no specific function. There were 33 of them in male professors' lectures and 40 of them in the lectures presented by female professors.

Similar to the significant difference between Iranian male and female professors regarding the number of times they used 'you know', there was a significant difference between English male and female professors about the number of times they used in their lectures; however, it is different in that, according to Table 6, Iranian male professors used 'you know' twice as many as female professors, while Table 7 shows that, English female professors used 'you know' almost twice as many as male professors (732 cases for male vs. 1450 for female professors). Besides, generally in all of the three sub-parts, female professors used more cases of 'you know' (372 cases for male vs. 480 for female in hearer-oriented; 108 cases for male vs. 241 for female in interactant-relationship-oriented; and 252 cases for male vs. 717 for female in speaker-oriented). 


\section{Table 7}

Frequency of Different Functions of 'you know' in English Male/Female Professors' Lectures

\begin{tabular}{|c|c|c|c|c|c|c|}
\hline \multirow[b]{2}{*}{ Discourse Marker 'You know' } & \multicolumn{3}{|c|}{ English Male Professors } & \multicolumn{3}{|c|}{ English Female Professors } \\
\hline & $\mathrm{F}$ & RF & $\mathrm{P}$ & $\mathrm{F}$ & RF & $\mathrm{P}$ \\
\hline Hearer-oriented & 372 & .508 & $50.8 \%$ & 480 & .331 & 33.1 \\
\hline Assumption-correction & 12 & .016 & $1.6 \%$ & 18 & .012 & $1.2 \%$ \\
\hline Introducing background information & 0 & 0 & $0 \%$ & 13 & .009 & $.9 \%$ \\
\hline Cause & 9 & .012 & $1.2 \%$ & 19 & .013 & $1.3 \%$ \\
\hline Reason & 0 & 0 & $0 \%$ & 13 & .009 & $.9 \%$ \\
\hline Result & 0 & 0 & $0 \%$ & 37 & .0255 & $2.55 \%$ \\
\hline Explicitness & 61 & .083 & $8.3 \%$ & 74 & .051 & $5.1 \%$ \\
\hline Reformulation & 85 & .116 & $11.6 \%$ & 95 & .0655 & $6.55 \%$ \\
\hline Exemplification & 143 & .195 & $19.5 \%$ & 72 & .0496 & $4.96 \%$ \\
\hline Seeking confirmation & 11 & .015 & $1.5 \%$ & 39 & .0269 & $2.69 \%$ \\
\hline Summarization & 32 & .043 & $4.3 \%$ & 58 & .04 & $4 \%$ \\
\hline Quotative & 19 & .025 & $2.5 \%$ & 42 & .0289 & $2.89 \%$ \\
\hline Interactant-relationship-oriented & 108 & .147 & $14.7 \%$ & 241 & .166 & $16.6 \%$ \\
\hline Justification & 18 & .024 & $2.4 \%$ & 20 & .0138 & $1.38 \%$ \\
\hline Conclusion & 25 & .034 & $3.4 \%$ & 104 & .0717 & $7.17 \%$ \\
\hline Softener of FTA & 26 & .035 & $3.5 \%$ & 36 & .025 & $2.5 \%$ \\
\hline Interactional repair & 11 & .015 & $1.5 \%$ & 0 & 0 & $0 \%$ \\
\hline Indicating marked expressions & 0 & 0 & $0 \%$ & 0 & 0 & $0 \%$ \\
\hline Indicating the most likely event & 7 & .009 & $.9 \%$ & 48 & .033 & $3.3 \%$ \\
\hline $\begin{array}{l}\text { Indicating the unspoken message to be } \\
\text { completed by the hearer }\end{array}$ & 21 & .028 & $2.8 \%$ & 33 & .0227 & $2.27 \%$ \\
\hline $\begin{array}{l}\text { Indicating the coming message is meant to be } \\
\text { evaluated }\end{array}$ & 0 & 0 & $0 \%$ & 12 & .008 & $.8 \%$ \\
\hline Speaker-oriented & 252 & .344 & $34.4 \%$ & 717 & .494 & $49.4 \%$ \\
\hline Hesitation marker & 56 & .076 & $7.6 \%$ & 269 & .185 & $18.5 \%$ \\
\hline Restart & 101 & .138 & $13.8 \%$ & 235 & .162 & $16.2 \%$ \\
\hline Approximator & 10 & .013 & $1.3 \%$ & 23 & .0158 & $1.58 \%$ \\
\hline Introducing a new topic & 52 & .071 & $7.1 \%$ & 63 & .0434 & $4.34 \%$ \\
\hline Indicating speaker attitude & 12 & .016 & $1.6 \%$ & 36 & .025 & $2.5 \%$ \\
\hline Mere filler & 21 & .028 & $2.8 \%$ & 91 & .0627 & $6.27 \%$ \\
\hline
\end{tabular}

By these, it is meant that overall, English female professors used 'you know' by far more than male professors, but they used a wider range of functions than male professors only in the first sub-part (where the orientation was on the listener(s)); nevertheless, in the second and third sub-parts (where the orientation was on the speaker, or on the interaction between the speaker and the listener(s)) both groups used the same range of functions for 'you know'. To be more detailed, one can see that, in the first sub-part, male professors did not use three of the functions (introducing background information, reason, and result), but female professors used 'you know' for all of the functions. In the second sub-part, two functions were not used by each group ('interactional repair' for female professors and 'indicating the coming message' for male professors with 'indicating marked expressions' shared for both groups). Last but not least, in the final sub-part, both groups have used all the functions. Meanwhile, among the three sub-parts, the last one has the most significant difference, the second one has less significant difference and the first sub-part, stands with the least significant difference between the two groups. The final issue was mere filler in which both groups have used 'you know' with no specific function. Here again, female professors used some 4.5 times more cases of 'you know' with no specific function than male professors. 


\section{Table 8}

Frequency of Different Functions of 'I mean' in Iranian Male/Female Professors' Lectures

\begin{tabular}{ccccccc}
\hline & \multicolumn{7}{c}{ Iranian Male Professors } & \multicolumn{3}{c}{ Iranian Female Professors } \\
\cline { 2 - 7 } Discourse Marker I mean' & $\mathrm{N}$ & $\mathrm{RF}$ & $\mathrm{P}$ & $\mathrm{N}$ & $\mathrm{RF}$ & $\mathrm{P}$ \\
\hline Hearer-oriented & 136 & .503 & $50.3 \%$ & 94 & .602 & $60.2 \%$ \\
Assumption-correction & 0 & 0 & $0 \%$ & 0 & 0 & $0 \%$ \\
Exemplification & 16 & .037 & $3.7 \%$ & 0 & 0 & $0 \%$ \\
Explicitness & 4 & .015 & $1.5 \%$ & 0 & 0 & $0 \%$ \\
Reformulation & 67 & .25 & $25 \%$ & 47 & .30 & $30 \%$ \\
Cause & 16 & .06 & $6 \%$ & 31 & .1987 & $19.87 \%$ \\
Reason & 6 & .022 & $2.22 \%$ & 0 & 0 & $0 \%$ \\
Result & 21 & .077 & $7.77 \%$ & 16 & .102 & $10.2 \%$ \\
Summarization & 6 & .022 & $2.22 \%$ & 0 & 0 & $0 \%$ \\
Softener of FTA & 46 & .17 & $17 \%$ & 31 & .1987 & $19.87 \%$ \\
Interactional repair & 0 & 0 & $0 \%$ & 0 & 0 & $0 \%$ \\
Justification & 10 & .037 & $3.7 \%$ & 5 & .032 & $3.2 \%$ \\
Conclusion & 26 & .096 & $9.6 \%$ & 26 & .166 & $16.66 \%$ \\
Speaker-oriented & 10 & .037 & $3.7 \%$ & 0 & 0 & $0 \%$ \\
Transaction repair & 88 & .325 & $32.5 \%$ & 31 & .1987 & $19.87 \%$ \\
Restart & 28 & .103 & $10.3 \%$ & 0 & 0 & $0 \%$ \\
Hesitation marker & 26 & .096 & $9.6 \%$ & 0 & 0 & $0 \%$ \\
Resumption & 16 & .06 & $6 \%$ & 0 & 0 & $0 \%$ \\
Indicating speaker attitude & 0 & 0 & $0 \%$ & 16 & .102 & $10.2 \%$ \\
Mere filler & 7 & .026 & $2.6 \%$ & 0 & 0 & $0 \%$ \\
& 11 & .04 & $4 \%$ & 15 & .096 & $9.6 \%$ \\
\hline
\end{tabular}

Similar to 'you know', the functions of 'I mean' were divided into three sub-parts of hearer-oriented, interactant-relationship-oriented, and speaker-oriented, too. Meanwhile, Table 8 is similar to Table 6 in that, the difference between the number of cases that male professors used 'I mean' is almost twice the number of cases female professors used it. So, quantitatively, male professors used more cases of 'I mean' than female professors. In the meantime, male professors used more cases of 'I mean' in all of the sub-parts overall. However, one major difference between Tables 6 and 8 is that in the latter one, female professors didn't use used 11 of the functions at all (e.g., assumption-correction, exemplification, explicitness, reason, summarization, softener of FTA, conclusion, transaction repair, restart, hesitation marker, and indicating speaker attitude), while this was male professors didn't use just 3 of the functions of 'I mean' in their lectures (assumption-correction, softener of FTA, and resumption). It should also be mentioned that of the three sub-parts, only in the last one was a significant difference between male and female professors and the difference between male and female uses of 'I mean' in the other two was less significant. From all these, one can conclude that Iranian male professors were by far better users of different functions of 'I mean' both quantitatively and qualitatively. That is, male professors used a much wider variation of the functions of 'I mean' in all of the sub-parts than female professors. Finally, both groups used some cases of 'I mean' as mere filler with no specific function ( 11 cases by male professors and 15 by female professors), but the difference was not significant at all.

Table 9 is completely different from Table 8 both qualitatively and quantitatively. As to the number of cases, 'I mean' was used by each group, one can see that female professors used three times more cases of 'I mean' than male professors (265 cases for male professors and 820 for female ones). Meanwhile, in all of the three sub-parts, female professors used by far more cases of 'I mean' than female professors (hearer-oriented, male 171 vs. female 492; intractant-relationship-oriented, male 43 vs. female 88; and speaker-oriented, male 51 vs. female 240). As it can be seen, of the three sub-parts, the third one has the most significant difference between the two groups and then comes the second part and finally, stand the first part. Too, male professors didn't use 6 of the 
Rezaee, M., Aghagolzadeh, F., \& Birjandi, P.

functions at all (assumption-correction, reason, justification, transactional repair, resumption, and indicating speaker attitude), while female professors didn't use only two of the functions (reason and conclusion). From what has been mentioned, the superiority of English female professors over their male counterparts (both qualitatively and quantitatively) can be concluded regarding the use of 'I mean' functions. That is, female professors used both a wider range of the functions of 'I mean' and a higher number of them. Finally, both groups used different number of cases of 'I mean' with no specific function and merely as filler in their lectures (25 cases for male professors and 14 for female professors).

Table 9

Frequency of Different Functions of 'I mean' in English Male/Female Professors' Lectures

\begin{tabular}{ccccccc}
\hline & \multicolumn{2}{c}{ English Male Professors } & \multicolumn{3}{c}{ English Female Professors } \\
\cline { 2 - 7 } Discourse Marker 'I mean' & $\mathrm{N}$ & $\mathrm{RF}$ & $\mathrm{P}$ & $\mathrm{N}$ & $\mathrm{RF}$ & $\mathrm{P}$ \\
\hline Hearer-oriented & 171 & .645 & $64.5 \%$ & 492 & .6 & $60 \%$ \\
Assumption-correction & 0 & 0 & $0 \%$ & 72 & .088 & $8.8 \%$ \\
Exemplification & 16 & .06 & $6 \%$ & 63 & .076 & $7.6 \%$ \\
Explicitness & 27 & .101 & $10.1 \%$ & 24 & .029 & $2.9 \%$ \\
Reformulation & 58 & .218 & $21.8 \%$ & 209 & .254 & $25.4 \%$ \\
Cause & 22 & .083 & $8.3 \%$ & 41 & .05 & $5 \%$ \\
Reason & 0 & 0 & $0 \%$ & 0 & 0 & $0 \%$ \\
Result & 23 & .087 & $8.7 \%$ & 62 & .075 & $7.5 \%$ \\
Summarization & 25 & .094 & $9.4 \%$ & 21 & .025 & $2.5 \%$ \\
Softener of FTA & 43 & .162 & $16.2 \%$ & 88 & .107 & 10.7 \\
Interactional repair & 17 & .064 & $6.4 \%$ & 23 & .028 & $2.8 \%$ \\
Justification & 14 & .052 & $5.2 \%$ & 19 & .023 & $2.3 \%$ \\
Conclusion & 0 & 0 & $0 \%$ & 46 & .056 & $5.6 \%$ \\
Speaker-oriented & 12 & .045 & $4.5 \%$ & 0 & 0 & $0 \%$ \\
Transaction repair & 51 & .192 & $19.2 \%$ & 240 & .292 & $29.2 \%$ \\
Restart & 0 & 0 & $0 \%$ & 27 & .033 & $3.3 \%$ \\
Hesitation marker & 12 & .045 & $4.5 \%$ & 71 & .086 & $8.6 \%$ \\
Resumption & 14 & .052 & $5.2 \%$ & 63 & .077 & $7.7 \%$ \\
Indicating speaker attitude & 0 & 0 & $0 \%$ & 37 & .045 & $4.5 \%$ \\
Mere filler & 0 & 0 & $0 \%$ & 28 & .034 & $3.4 \%$ \\
& 25 & .094 & $9.4 \%$ & 14 & .017 & $1.7 \%$ \\
\hline
\end{tabular}

Illustrating the findings in percentage, as it is done in Tables 2 to 9 might present a more comprehensive overview of the results, and so, we will get to Tables 10 and 11 which show the number of times each of the 4 DMs was used in the two groups of Iranian male and female professors and also English male and female professors.

\section{Table 10}

Frequency \& Percentage of the Functions of DMs in Iranian Male/Female Professors' Lectures

\begin{tabular}{ccccc}
\hline & \multicolumn{2}{c}{ Iranian Male Professors } & \multicolumn{2}{c}{ Iranian Female Professors } \\
\cline { 2 - 5 } Discourse Marker & $\mathrm{F}$ & $\mathrm{P}$ & $\mathrm{F}$ & $\mathrm{P}$ \\
\hline Well & 319 & $.24 \%$ & 360 & $.27 \%$ \\
OK & 729 & $.54 \%$ & 920 & $.70 \%$ \\
You know & 749 & $.56 \%$ & 395 & $.30 \%$ \\
I mean & 270 & $.20 \%$ & 156 & $.12 \%$ \\
Average & 516.75 & $.38 \%$ & 457.75 & $.35 \%$ \\
\hline
\end{tabular}

Table 10 shows a close comparison and contrast between Iranian male and female professors regarding the frequency of each of the DMs together their percentages concerning the total number of words used in the lectures of each group. As the average of the two groups shows, no significant difference can be seen between Iranian male and female professors regarding the functions of the four DMs used in their lectures. 
The effect of lecturers' gender on the use of discourse markers

Table 11

Frequency \& Percentage of the Functions of DMs in English Male/Female Professors' Lectures

\begin{tabular}{ccccc}
\hline & \multicolumn{2}{c}{ English Male Professors } & \multicolumn{2}{c}{ English Female Professors } \\
\cline { 2 - 5 } Discourse Marker & $\mathrm{F}$ & $\mathrm{P}$ & $\mathrm{F}$ & $\mathrm{P}$ \\
\hline Well & 540 & $.40 \%$ & 1100 & $.81 \%$ \\
OK & 780 & $.57 \%$ & 970 & $.71 \%$ \\
You know & 732 & $.54 \%$ & 1450 & $1.06 \%$ \\
I mean & 265 & $.19 \%$ & 820 & $.60 \%$ \\
Average & & & & $.79 \%$ \\
\hline
\end{tabular}

Alternatively, Table 11 shows a more significant difference between English male and female professors concerning the percentage of the functions of the four DMs used in their lectures. However, since the research question of the present study considers gender of both Iranian and English professors, we get to Table 12 which is the average of the percentage of the functions of the four DMs used in Iranian and English male professors against Iranian and English female professors.

Table 12

Frequency \& Percentage of the Functions of DMs in Iranian \& English Male/Female Professors' Lectures

\begin{tabular}{ccccc}
\hline & \multicolumn{2}{c}{ Iranian and English Male Professors } & \multicolumn{2}{c}{ Iranian and English Female Professors } \\
\cline { 2 - 5 } Discourse Marker & $\mathrm{F}$ & $\mathrm{P}$ & $\mathrm{F}$ & $\mathrm{P}$ \\
\hline Well & 859 & $.32 \%$ & 1460 & $.54 \%$ \\
OK & 1509 & $.55 \%$ & 1890 & $.70 \%$ \\
You know & 1481 & $.55 \%$ & 1845 & $.68 \%$ \\
I mean & 535 & $.19 \%$ & 976 & $.36 \%$ \\
Average & 1096 & $.40 \%$ & 1542.5 & .57 \\
\hline
\end{tabular}

Based on Table 12, one can see that Iranian and English male professors had an average frequency of 1096 and an average of $.40 \%$ regarding the pragmatic functions of the four DMs that they used in their lectures, while Iranian and English female professors had an average frequency of 1542 and an average of $.57 \%$ as to the pragmatic functions of the four DMs they used in their lectures. As it can be seen, quantitatively, Iranian and English female professors used almost 1.5 times more functions of the four DMs overall and based on the tabulation of the frequencies and functions for each DM, on the whole, Iranian and English female professors used a wider variety of the pragmatic functions of the four DMs. Put another way, besides being superior quantitatively, Iranian and English female professors were superior qualitatively, too. That is, they used a wider variety of DM functions than Iranian and English male professors in their lectures. Thus, one can conclude that gender has a significant effect on the use of DMs and their pragmatic functions and so, there is a significant difference between Iranian and English male professors and their female counterparts regarding their use of DMs and the pragmatic functions of those DMs.

\section{Conclusion}

The aim of the present study was to find possible gender differences in the use of four discourse markers ('Well', 'OK', 'You know' and 'I mean') together with their pragmatic functions. On the basis of the corpus selected for analysis in both Iranian and English contexts, one can conclude that contrary to previous studies (Koczogh \& Furko, 2011), there are substantial quantitative and qualitative differences in the use of DMs and their pragmatic functions in the lectures presented by Iranian and English male and female professors. This is in line with what some other researchers have stated (Chun, 2008; Escalera, 2006; Kim \& Kang, 2011; Kyratzis \& Ervin Tripp, 1999; Liao, 2008; Matei, 2011; Mei, 2006; Winkler, 2008, to name but a few). Interestingly enough, the findings of the present study support Alami and Sabbah's (2012) and Yeganeh and Ghoreishi's (2014) findings which were carried out in Iranian EFL contexts. 
Finally, it can be concluded that since the Iranian and English female professors used more of the four DMs quantitatively and also employed a wider range of the functions of the DMs qualitatively, compared to their male counterparts, this can account for female professors' inclination to make use of discourse markers as helpful devices in fulfilling their communicative needs. There might be various explanations regarding the findings. Female instructors may have used more DMs in the present study since they have possibly encountered more memory load. As Mason (2008) explains, memory load may lead one to make use of DMs in one's speech. Perhaps, another possible explanation as to the higher amount of the employment of DMs by females is that female instructors are interested in gaining more positive acknowledgment from the audience. Yet, they may wish to establish a stronger shared universe of discourse than their male counterparts. This might be due to the female instructors' inclination to draw students' attention to what goes on in the classroom and encourage them to get involved in the discussions. Still another explanation for higher number of DMs used by female professors might be because they wish to convey more accurate meaning and transfer their ideas to their students more minutely (Zarei, 2013).

Further studies, however, need to be carried out in order to investigate female instructors' higher percentage of DM use. Other studies also should explore whether across different age groups, female and male instructors use different amount of DMs. Furthermore, more studies need to be carried out in order to see whether female instructors use DMs when they address male students or female ones. In the meantime, more studies need to be carried out in order to see if the same result would be gained in classes of other majors/disciplines (other than social sciences).

\section{References}

Ädel, A. (2010). Just to give you kind of a map of where we are going: A taxonomy of metadiscourse in spoken and written academic English. Nordic Journal of English Studies, 9(2), 69-97.

Aijmer, K., \& Simon-Vandenbergen, A. M. (2009). Pragmatic markers. In J. O. Östman \& J. Verschueren (Eds.), Handbook of pragmatics (pp. 31-100). Amsterdam: John Benjamins Publishing Company. http://dx.doi.org/10.1075/hop.13.pra4

Alami, M., \& Sabbah, M. (2012). Gender and discourse difference: An investigation of discourse markers in Persian male-female casual conversation. Persian Language Scientific Research Quarterly, 10(1), 1-17.

Andersen, G. (2001). Pragmatic markers and sociolinguistic variation: A relevance-theoretic approach to the language of adolescents. Amsterdam: John Benjamins Publishing Company. http://dx.doi.org/10.1075/pbns.84

Asthana, H. S., \& Bhushan, B. B. (2010). Statistics for social sciences: With SPSS applications. New Delhi: Prentice-Hall. Books google.

Baker, P. (2010). Sociolinguistics and corpus linguistics. Edinburgh: Edinburgh University Press.

Beeching, K. (2002). Gender, politeness and pragmatic particles in French. Amsterdam: John Benjamins Publishing Company. http://dx.doi.org/10.1075/pbns.104

Bellés Fortuño, B. (2006). Discourse markers within the university lecture genre: A contrastive study between Spanish and North American lectures. Unpublished $\mathrm{PhD}$ dissertation. Castelló: Universitat Jaume.

Benson, M. J. (1994). Lecture listening in an ethnographic perspective". In J. Flowerdew (Ed.), Academic English: Research perspectives (181-198). Cambridge: Cambridge University Press.

Blakemore, D. (1987). Semantic constraints on relevance. Oxford: Blackwell.

Blakemore, D. (1992). Understanding utterances: An introduction to pragmatics. Oxford: Blackwell.

Blakemore, D. (2002). Relevance and linguistic meaning: The semantics and pragmatics of discourse markers. Cambridge: Cambridge University Press. http://dx.doi.org/10.1017/CBO9780511486456

Carter, R., \& McCarthy, M. (2006). Cambridge grammar of English. Cambridge: Cambridge University Press.

Chaudron, C. (1983). Simplification of input: topic reinstatements and their effects on L2 learners' recognition and recall. TESOL Quarterly, 17(3), 437-458. http://dx.doi.org/10.2307/3586257

Chaudron, C., \& Richards, J. (1986). The effect of discourse markers on the comprehension of lectures. Applied 
The effect of lecturers' gender on the use of discourse markers

Linguistics, 7(2), 113-127. http://dx.doi.org/10.1093/applin/7.2.113

Christodoulidou, M. (2011). Lexical markers within the university lecture. Novitas-ROYAL (Research on Youth and Language), 5(1), 143-160.

Chun, C. X. (2008). An investigation of discourse markers across gender in non-English majors' argumentative writings in English. Unpublished MA Thesis. Xinjiang Normal University.

Cohen, E. (2007). Discourse markers: Cotext and context sensitivity. Proceedings of the Israeli Linguistic Society, 16, v-xxiii.

Croucher, S. M. (2004). Like, you know, what I'm saying: A study of discourse marker frequency in extemporaneous and impromptu speaking. National Forensic Journal, 22(2), 38-47.

Erman, B. (1987). Pragmatic expressions in English: A study of You know, You see and I mean in face-to-face conversation. Stockholm: English Department, Stockholm University.

Escalera, E. A. (2006). Gender difference in children's use of discourse markers: Separate worlds or different contexts? Journal of Pragmatics, 41, 2479-2495. http://dx.doi.org/10.1016/j.pragma.2006.08.013

Eslami-Rasekh, Z., Eslami-Rasekh, A., \& Simin, S. (2012). North American and Iranian EFL lecturers' use of discourse markers: The cross-cultural aspects. The Proceeding of 1st Conference on Language Learning \& Teaching: An Interdisciplinary Approach (LLT-IA). Mashhad, Iran.

Fischer, K. (2000). Discourse particles, turn-taking, and the semantics-pragmatics interface. Retrieved December 2012, from http://nats-www.informatik.uni-hamburg.de/fischer/rspfischer.pdf

Fortanet Gomez, I., \& Bellés Fortuño, B. (2005). Spoken academic discourse: An approach to research on lectures. Revista española de lingüística aplicada, 1, 161-178.

Fox Tree, J. E., \& Schrock, J. C. (2002). Basic meanings of you know and I mean. Journal of Pragmatics, 34 , 727-747. http://dx.doi.org/10.1016/S0378-2166(02)00027-9

Fraser, B. (1990). An approach to discourse markers. Journal of Pragmatics, 14, 383-395. http://dx.doi.org/10.1016/0378-2166(90)90096-V

Fraser, B. (1996). Pragmatic markers. Pragmatics, 6(2), 167-190.

Fraser, B. (1999). What are discourse markers? Journal of Pragmatics, 31, 931-952. http://dx.doi.org/10.1016/S0378-2166(98)00101-5

Fuller, J. M. (2003). The influence of speaker on discourse marker use. Journal of Pragmatics (35), 23-45. http://dx.doi.org/10.1016/S0378-2166(02)00065-6

Halliday, M. A. K. (1994). An introduction to functional grammar $\left(2^{\text {nd }}\right.$ ed.). London \& New York: Arnold.

Hitchcock, G., \& Hughes, D. (2003). Research and the teacher: A qualitative introduction to school-based research ( $2^{\text {nd }}$ ed.). London and New York: Routledge.

Holzschuh, E. (2013). Discourse marker use in ELF conversations: The case of "you know". Retrieved February 2014, from http://www.univie.ac.at/voice/holzschuh_2013.pdf

Jones, L. K. (1992). In pursuit of discourse particles. In S. J. J. Hwang \& W. R. Merrifield (Eds.), Language in context: Essays for Robert E. Longacre (pp. 127-136). Texas: The University of Texas.

Jucker, A. H. (1993). The discourse marker well: A relevance-theoretical account. Journal of Pragmatics, 19, 435-452. http://dx.doi.org/10.1016/0378-2166(93)90004-9

Kaveifard, E., \& Allami, H. (2011). Inferential discourse markers in discussion section of psychology research articles across English and Persian. Theory and Practice in Language Studies, 1(12), 1786-1791. http://dx.doi.org/10.4304/tpls.1.12.1786-1791

Khedri, M., Ebrahimi, S. J., \& Heng, C. S. (2013). Interactional metadiscourse markers in academic research article result and discussion sections. The Southeast Asian Journal of English Language Studies, 19(1), 65-74.

Kim, H., \& Kang, B. (2011). Gender and usage of discourse markers in spoken Korean. Proceedings of the 16th Conference of Pan-Pacific Association of Applied Linguistics, 30-31.

Koczogh, H. V., \& Furkó, B. P. (2011). Gender differences in the use of the discourse markers you know and I mean. Argumentum 7, 1-18.

Kyratzis, A., \& Ervin Tripp, S. (1999). The development of discourse markers in peer interaction. Journal of Pragmatics, 31, 1321-1338. http://dx.doi.org/10.1016/S0378-2166(98)00107-6 
Rezaee, M., Aghagolzadeh, F., \& Birjandi, P.

Lee, K. (2011). Teaching discourse markers Well and Oh. Retrieved February 2014, from www.indiana.edu/ dsls/publications/LeeWell.pdf

Lee, B. C., \& Hsieh, C. J. (2004). Discourse marker teaching in college conversation classrooms: Focus on WELL, YOU KNOW, I MEAN. General Education Annual Digest, 6, 177-199.

Li, M., \& Xiao, Y. (2012). A comparative study on the use of the discourse marker "Well" by Chinese learners of English and native English speakers. International Journal of English Linguistics, 2(5), 65-71. http://dx.doi.org/10.5539/ijel.v2n5p65

Liao, S. (2008). Variation in the use of discourse markers by Chinese teaching assistants in the US. Journal of Pragmatics, 41, 1313-1328. http://dx.doi.org/10.1016/j.pragma.2008.09.026

Mason, M. (2008). Courtroom interpreting. Maryland: University Press of America.

Matei, M. (2011). The influence of age and gender on the selection of discourse markers in casual conversations. Bulletin of the Transilvania University of Braşov. Series IV: Philology and Cultural Studies, 4(53), No. 1, 213-220.

Mei, L. Y. (2006). Research on gender differences in the employment of discourse markers. Unpublished MA Thesis, Chengdu University of Technology.

Mei, W. (2012). A corpus-based comparative study of pragmatic markers: I mean and you know in native and non-native conversation. Unpublished doctoral dissertation, University of Liverpool, England.

Mesthrie, R. (2001). (Ed.), Concise encyclopaedia of sociolinguistics. Kidlington: Elsevier Science Ltd.

Navas Brenes, C. A. (2005). Analyzing an oral narrative using discourse analysis tools: Observing how discourse analysis works. Revista Electrónica “Actualidades Investigativas en Educación”, 5(1), 1-19.

Nosek, J. (1987). Constitutive, informative and transformative models in modern English texts and sentences. In R. Dirven \& V. Fried (Eds.), Functionalism in Linguistics (pp. 157-168). Amsterdam/Philadelphia: John Benjamins Publishing Company.

Othman, Z. (2010). The use of okay, right and yeah in academic lectures by native speaker lecturers: Their 'anticipated' and 'real' meanings. Discourse Studies, 12(5), 665-681. http://dx.doi.org/10.1177/1461445610376365

Quirk, R., Greenbaum, S., Leech, G., \& Svartvik, J. (1985). A comprehensive grammar of the English language. London: Longman.

Rahimi Tehrani, A., \& Vahid Dastjerdi, H. (2012). The pedagogical impact of discourse markers in the lecture genre: EFL learners' writings in focus. Journal of Language Teaching and Research, 3(3), 423-429. http://dx.doi.org/10.4304/jltr.3.3.423-429

Rashidi, N., \& Alhosseini, F. (2012). A contrastive study of metadiscourse markers in research article abstracts across disciplines. Bulletin of the Transilvania University of Braşov: Series 5, Philology and Cultural Studies, 54(2), 17-23.

Redeker, G. (1990). Ideational and pragmatic markers of discourse structure. Journal of Pragmatics, 14(3), 367-381. http://dx.doi.org/10.1016/0378-2166(90)90095-U

Richards, J. C., \& Schmidt, R. (2010). Longman dictionary of language teaching and applied linguistics (4 $\left.{ }^{\text {th. }} \mathrm{ed}.\right)$. Edinburgh: Pearson Education Limited.

Rido, A. (2010). The use of discourser markers as an interactive feature in science lecture discourse in L2 setting. TEFLIN Journal: A publication on the teaching and learning of English, 21(1), 90-106.

Rose, R. A. (1998). A look at lecture discourse in the EFL classroom. Faculty Research Publication, Hiroshima Notre Dame Seishin Junior College, 21, 41-67.

Schiffrin, D. (1987). Discourse markers. Cambridge: Cambridge University Press. http://dx.doi.org/10.1017/CBO9780511611841

Schleef, E. (2008). The 'lecturer's OK' revisited: Changing discourse conventions and the influence of academic division. American Speech, 83(1), 62-84. http://dx.doi.org/10.1215/00031283-2008-003

Shahbaz, M., Sheikh, O. I. \& Ali, M. S. (2013). Use of discourse markers by Chinese EFL professors: A corpus-based Study of academic lectures by natives and non-natives. Journal of Education and Practice, 4(5), 80-90.

Simpson, R. C., Briggs, S. L., Ovens, J., \& Swales, J. M. (Eds.). (2002). Corpus linguistics in North America. 
Ann Arbor, MI: The University of Michigan Press.

Smit, T. C. (2009). The academic lecture: Learn to listen or listen to learn? Nawa Journal of Language and Communication, 3(1), 1-18.

Swerts, M. (1998). Filled pauses as markers of discourse structure. Journal of Pragmatics, 30, 485-496. http://dx.doi.org/10.1016/S0378-2166(98)00014-9

Tannen, D. (2007). Talking voices: Repetition, dialogue, and imagery in conversational discourse. Cambridge: Cambridge University Press. http://dx.doi.org/10.1017/CBO9780511618987

Trihartanti, R. P., \& Damayanti, D. M. (2013). The use of 'oh' and 'well' as discourse markers in conversation of Bandung state Polytechnic students. Retrieved February 2014, from www.fllt2013.org/private_folder/Proceeding/762.pdf

Vandan, K. H., \& Péter, F. B. (2011). Gender differences in the use of the discourse markers 'you know' and 'I mean'. Argumentum, 7, 1-18.

Waggoner, M. (1984). The new technologies versus the lecture tradition in higher education: is change possible? Educational Technology 24(3), 7-12.

Watanabe, M. (2002). Fillers as indicators of discourse segment boundaries in Japanese monologues. Retrieved August 2014, from http://sprosig.isle.illinois.edu/sp2002/pdf/watanabe.pdf

Winkler, E. G. (2008). A gender-based analysis of discourse markers in Limonese creole. Sargasso: A Journal of Caribbean Literature, Language \& Culture, 53-72.

Yeganeh, M. T., \& Ghoreishi, S. M. (2014). Exploring gender differences in the use of discourse markers in Iranian academic research articles. Global Journal of Guidance and Counselling. 4(1), 06-12.

Yule, G. (2006). The study of language ( $3^{\text {rd }}$ ed.). Cambridge: Cambridge University Press.

Zarei, F. (2013). Discourse markers in English. International Research Journal of Applied and Basic Sciences, $4(1), 107-117$. 
Rezaee, M., Aghagolzadeh, F., \& Birjandi, P. 